\title{
Administrative Reform and Rule of Law in China
}

\author{
Zou KeYuan
}

\begin{abstract}
Rule of Law has become popular jargon in Chinese society since its adoption in the Third Amendment to the Chinese Constitution in 1999. After the transition of the Chinese leadership from the Third Generation to the so-called Fourth Generation, a significant new document, issued in April 2004, ushered in a new era of administrative reform in China. China's pledge is to have established a rule-of-law government by 2015. This article discusses new developments and legal aspects of administrative reform and evaluates whether the rule-of-law concept has been fully endorsed in China. Finally, it presents a brief discussion on the relationship between the Chinese Communist Party and the law, which is intrinsic to the success of China's administrative reform. ${ }^{1}$
\end{abstract}

\section{Introduction}

The 'rule of law' (fazhi) was first endorsed by the People's Republic of China (PRC) at the time of the adoption of the 1999 Third Amendment to the Chinese Constitution (Article 5, 1999 Amended Constitution). ${ }^{2}$ Shortly afterwards in November 1999, the State Council issued a Decision on Comprehensively Pushing Forward Administration in Accordance with the Law, ${ }^{3}$ requesting local governments at all levels and subordinated departments of the State Council to strengthen institutional building, tighten administrative law enforcement, deepen supervision for administrative law enforcement, and increase the capacity of the administration in accordance with the law. The most significant event took place just after the Fourth Generation of the Chinese leadership came to power, when in April 2004, the Implementing Program of Comprehensively Pushing forward Administration in Accordance with Law (yi fa xing zheng) was issued (People's Daily, 21 April 2004:6).

There are several reasons that account for China's decision to introduce this change in approach. First, since the economic reform and open-door policy of 1978, Chinese society has undergone fundamental 
changes both in its economic development and in the reconstruction of its legal system. Economic reform, which transformed the old planned economy into a longer-term, more market-oriented paradigm, has brought prosperity to the Chinese society. The watershed occurred when the National People's Congress (NPC) made a significant amendment to the Constitution by endorsing the term 'socialist market economy' to replace the old term 'planned economy' in March 1993 (People's Daily, 30 March 1993). To support this constitutional change, the $3^{\text {rd }}$ Plenum of the $14^{\text {th }}$ Congress of the Chinese Communist Party (CCP) adopted the historic Decision on Issues Concerning the Establishment of a Socialist Market Economic Structure in November 1993 (China Daily, 17 November 1993). ${ }^{4}$ It is commonly said that a market economy is a rule-of-law economy. For this reason, law is indispensable for the development of the Chinese market-oriented economy and the new type of governance over economic activities.

The legal field has also witnessed many significant changes. The $3^{\text {rd }}$ Plenary Session of the $11^{\text {th }}$ CCP Central Committee, held in December 1978, adopted the communique setting out the goals of the legal construction and re-establishment (Quarterly Chronicle and Documentation 1979: 172). As a result, a legal system has been gradually built up alongside the economic reform. As officially pledged, China will have established a comprehensive legal system by 2010.

The requirements from the World Trade Organization (WTO) constitute a second main factor for the transformation in China's legal environment and law enforcement rationale and methods. As a WTO member, China has to bring its relevant laws and regulations in line with those of the organization; those that are in conflict with WTO rules have to be revised and/or abolished. The WTO effect is therefore fundamental to the change in Chinese legislation that is presently taking place, and this will continue for some years to come. Also, the WTO requires its member governments to behave in accordance with its requirements, including transparency and accountability.

Third, China has carried out its 'Popularizing Law Program' for more than 20 years since 1985. It is designed to give ordinary people a basic legal knowledge so as to raise their legal awareness and help them to act within the law. Teams of lecturers from universities and other work units were set up to give lecture tours around the country. ${ }^{5}$ Even the Chinese top leaders invited law professors to give seminars on current legal issues for the members of the Chinese Communist Party (CCP)'s Central Committee and the Standing Committee of the National People's 
Congress (NPC). ${ }^{6}$ Despite these efforts, it is admitted that of the 6.3 million or so civil servants, a large number of local cadres including law enforcers do not have a good grounding in legal matters (People's Daily, 5 December 2006:10). Some even perceive administrative officials to be 'one of the major obstacles to the rule of law' since "[they] regularly abuse their authority, ignore central laws, and pass inconsistent administrative regulations that promote their own institutional interests' (Perenboom, 2006:66-7). Thus administrative reform geared towards the rule of law is becoming a matter of urgency along with the strengthening of China's economic reform and reforms in other areas.

Finally, the Chinese government has learnt a lesson from the severe acute respiratory syndrome (SARS) incident in 2003. The poor administration and management in the early period of the crisis contributed to the escalation of the disease within and outside China. For example, the relevant government department tried to conceal critical information from the public. However, the Chinese government finally realized the importance of law and used the 1989 Law on Prevention and Control of Infectious Diseases to combat the epidemic. Measures were accordingly taken to set up quarantine zones in affected areas and to activate the system of reporting and publicizing SARS cases. Information on SARS was given to the public in time. ${ }^{7}$

The change of the Chinese leadership may also have some impact on the advancement of the legal reform process and the raising of legal awareness within Chinese society. It is to be recalled that $\mathrm{Hu}$ Jintao, before he took over all the top posts from Jiang Zemin, emphasized the importance of abiding by the Constitution and called in December 2002 for all cadres to respect its legal authority - the occasion was the twentieth anniversary of the promulgation of the 1982 Constitution. $\mathrm{Hu}$ has often expressed his belief in governing the country by establishing the Party for the public and using the power for the people.

\section{Implementing Law-Based Administration}

For the administration to be in accordance with the law, several key components are required. While the Implementation Program provides basic guidelines, administrative laws are also indispensable to its successful adoption. 


\section{The Implementation Program}

According to this document, China will spend ten years constructing a rule of law government, with the target set for around 2015. Several objectives have been delineated:

1. To separate government from enterprises and public institutions (shiye danwei) in order to: (a) improve the relationships between the government and the market and between the government and the society; (b) differentiate clearly the functions and responsibilities between, on the one side, the central and local governments and, on the other, the respective government departments; and (c) to formulate an administrative management system which becomes normative, coordinative, transparent and efficient.

2. To put forward and adopt local and administrative laws and regulations and normative documents in conformity with the competence and procedures prescribed by the Constitution and relevant national laws.

3. To implement laws and regulations in a comprehensive and accurate way so as to effectively maintain economic and social order.

4. To formulate a scientific, democratic and normative decision-making mechanism to reflect the wishes and needs of the people.

5. To formulate a mechanism to resolve social conflicts.

6. To link administrative power to responsibility and to improve the supervision mechanism

7. To heighten the legal awareness of administrative personnel, particularly leading cadres (2004 Implementation Program).

The document provides six basic requirements for law-based administration, including lawful administration; reasonable administration; rightful procedure; efficiency and provision of convenience for the people; honesty; and power and responsibility combined. It offers guidelines on other areas of administration to deepen the institutional reform in compliance with relevant laws.

It is understandable that in the post-WTO era, governments at all levels in China are having to rethink and change their methods of administration and governance. Law will become more and more important in government management. Law is designed to limit the government's power, to establish adequate administrative procedures, and to foster the concept of responsible governance. There are a number of special laws regarding administration in China, which will be discussed later. The most important one in the present context is the Law on Administrative 
Licensing, which was passed in August 2003 and came into force on 1 July 2004 (People's Daily, 28 August 2003:13; Meng 2004; China Daily, 1 July 2004).

A recent development has been that local governments are beginning to hire lawyers to assist them in their work. For example, in November 2003, the Government of Shenzhen set up an Office of Legal Counsels, who participate in big project negotiations and in finalizing contracts, in addition to litigation work. In early 2007 it invited applicants to compete for 18 positions as government lawyers (Ming Pao, 16 January 2007).

\section{Law on Administrative Licensing}

This law defines 'administrative licensing' as the conduct of an administrative body to examine and approve a specified activity which is being applied for. ${ }^{8}$ In the economic field, public health, macro-economic adjustment and control, ecological environmental protection, and the development and utilization of limited natural resources all require administrative licensing. Any regulation on administrative licensing has to be publicized, in order to become the basis for the granting of such a license. ${ }^{9}$ A citizen, legal person or other organization enjoys the right to presentation and explanation, the right to apply for administrative review, or to launch administrative litigation. The new law explicitly forbids government agencies from assuming the right to grant permits or collect fees not required by the law. In order to prevent localism, the law specifically provides that any administrative licensing at a certain locality should not restrict individuals and enterprises from other regions from conducting operations or providing services, nor can it restrict commodities from other regions being brought into the local market. ${ }^{10}$

The new law is regarded as an attempt by the Chinese government to facilitate the start-up of more small and medium-sized enterprises (SMEs), which help to boost employment (The Straits Times, 30 August 2003:1). Through the implementation of the law, the amount of administrative licensing will be greatly reduced and departments under the State Council will no longer have the right to determine whether a particular economic activity requires an administrative permit.

In order to reduce the number of items subject to administrative examination and approval, the State Council established a Group Office for the Reform of the Administrative Examination and Approvals System to conduct a comprehensive review. Through this rigorous process, between October 2002 and May 2004 the State Council decided to remove or modify 1,795 items on the list, accounting for half of the original amount. 
The State Council and its departments still retain 1,799 items which are divided into two categories: administrative licensing items and non-administrative licensing (People's Daily,6 February 2005:4). As for the whole country, $60 \%$ of the total number of items for administrative examination and approval are prescribed by State Council department regulations and rules (Huang and Han 2004), so that the reduction of the items by the State Council and its departments in fact reduces the same items at the local level.

While the law has been hailed as 'a great help in China's efforts to build a market economy and check corruption' (China Daily, 1 September 2003), its implementation will meet a series of challenges. First, the law only provides general principles which result in ambiguities and may in practice result in unenforceable legislation. Second, the progressive legal spirit embodied in the law may not be endorsed by local governments at all levels. Officials have tended to retain administrative power as long as they can, and 'the implementation of the law will inevitably conflict with vested interests' (China Daily, 6 September, 2003).

\section{Law on Administrative Punishment}

This law governs the administrative activities relating to punishment for violations. It sets out several principles:

1. No punishment shall be ever imposed when there is no express stipulation for such punishment.

2. The power to prescribe in terms of punishment for personal rights or property rights only belongs to the law.

3. The procedure for administrative punishment is for the first time detailed in the law, particularly the hearings system which is quite new in China.

The Measures on Administrative Punishment adopted by the Banking Supervisory Committee in 2004 provide that the person concerned has the right to apply for a hearing under certain circumstances (for example, if the punishment involves a large fine or a cessation order to stop business, or a revocation of a banking licence) before the punishment is imposed (International Financial Daily, 4 January 2005:2). For these reasons, it is a major milestone for the rule of law in China (Ying 1998:19-20). Following this law, other major laws were also enacted, such as the Law on Administrative Review Procedure adopted in April 1999 and the Law on Civil Servants adopted in April 2005.

The latest development in administrative law is linked to the WTO requirements. On the one hand, governments at all levels should ad- 
minister by law and on the other they should follow the transparency principle set forth by the WTO law. The publicizing requirement stipulated in the Administrative Licensing Law is a typical example. In addition, after its admission to the WTO, China can no longer use a large number of normative internal documents to govern the society. Instead, the government documents, when needed and in line with the WTO regulations, have to be reflected in the form of laws and regulations. For that purpose, during the SARS period, various government departments passed a large number of administrative regulations concerning public health, transportation, protection of wildlife and environment, prices, etc.

Problems, however, still persist in the law-based administration. First, not all officials and/or government departments are familiar with this new governance method, as evidenced by the fact that some still issued internal documents during the SARS period. That is why there is a saying in China that too many 'red dotted documents' (hongtou wenjian) are based on administrative discretion, and therefore may be subject to an abuse of administrative power. In order to avert this, the role of people's congresses should be strengthened and the government power endorsed through legislation (Cheng 2003). In a transitional society like China, such old practices may co-exist for a time alongside the new practices, but the new one will eventually replace the old one completely. Some deficiencies also remain in the implementation of the Law on Administrative Licensing since it came into force in July 2004:

- The mentality of some leading officials has not changed; they still stick to the old administrative method or do not clearly understand the law.

- It is a difficult task to balance the various implementation measures including the freedom of information system, the hearings system, and the responsibility system.

- There has been no effective clean-up of unapproved items.

- There is a lack of unified standards for non-licensed items subject to administrative approval.

- There have been unlawful fee charges for administrative licensing (Legal Daily, 1 July 2005).

As for the improvement of administrative laws, there was a call in 2006 by NPC deputies for a Law on Administrative Organization and Law on Administrative Bianzhi (People's Daily, 5 December 2006:10). 


\section{Law on Civil Servants}

China's civil service was established in the early 1990s. According to one source, there were about 6.37 million civil servants and more than 30 million personnel working in public-funded organizations in China by the end of 2003. ${ }^{11}$ Each year a national examination to recruit new civil servants takes place. In order to regulate the increasing body of civil servants, China adopted the Law on Civil Servants in April 2005, which took effect on 1 January 2006 (People's Daily 28 April 2005:10). It is designed to define officials' rights and responsibilities. According to the law, a civil servant is a person who performs his/ her public service in accordance with the law, is recruited into the state administrative bianzhi, and enjoys salary and benefits from the state finance (Article 2). $\mathrm{He} /$ she should meet the following qualifications: be a Chinese citizen, be at least 18 years old, uphold the Chinese Constitution, be of good conduct and good health, and have the education and working skills required for the position (Article 11).

This law sets out the requirement for public servants to be recruited through just, open and fair examinations. Officials should take the blame and quit their posts if their mistakes or negligence should cause major losses or serious social repercussions. Precise procedures have been delineated for civil servants to appeal against decisions they disagree with in order to determine their legal responsibilities. A stable salary system ensures that salaries are in line with the local economic levels and that they increase in line with the economic growth.

The CCP Ministry of Organization and the Ministry of Personnel issued the Regulations on the Performance Evaluation of Civil Servants (Trial) in January 2007. It contains six chapters and 31 clauses. According to its provisions, performance will be evaluated annually and divided into four levels: excellent, good, satisfactory and unsatisfactory. The number for excellence should be normally within 15 percent and not exceed 20 percent of the total in a government body (People's Daily, 18 January 2007:4). The evaluation is an important part of the civil service.

\section{The Take the Blame and Resign' System}

In addition to the law-based administration, a 'take the blame and resign' regime (yinjiu cizhi zhi) has been established. It began during the SARS period when the Mayor of Beijing and Minister of Health resigned due to their ineffective performance. In April 2004 the Provisional Regulations on the Resignation of Leading Cadres of the Party and the Gov- 
ernment were adopted. The scope of resignation has been expanded to all party and government organs. In the same month, Premier Wen Jiabao chaired a State Council standing meeting which dealt with three serious accidents, namely the Chuandong blowout accident; the Miyun Hongqiao stampede; and the Jilin Zhongbai shopping mall fire. The State Council approved the resignation of Ma Fucai, General Manager of the Sinopec for the blowout accident. Some of the responsible persons for the Miyun accident were brought to the court on criminal charges including negligence. ${ }^{12}$ The milk powder scandal in Anhui Province in April 2004 is a new addition to the previous cases: 97 people in local governments and supervision departments were held responsible for the inferior quality milk products which caused the death of at least 12 babies in Fuyang (China Daily, 8 November 2004:1). The Songhua River pollution incident in November 2005 caused several officials to be sacked ${ }^{13}$ and the head of the State Administration of Environmental Protection took the blame and finally resigned.

The 'take the blame and resign' system is now incorporated into the newly adopted Law on Civil Servants. According to Article 82, leading civil servants may resign for personal or other reasons; those who have acted improperly or caused serious loss or social impact as a result of accidents should assume the responsibility and resign, otherwise they will be ordered to do so. ${ }^{14}$ This can be seen as a further step of the Chinese Government to institutionalize the WTO requirement of accountability in its legal system and governance.

The State Council issued the Certain Opinions on Carrying out the Responsibility System for Administrative Law Enforcement in July 2005 (People's Daily, 28 July 2005:2). It was based on three considerations: (a) to implement the 2004 Implementation Program; (b) to govern and supervise law enforcement activities of the government; and (c) to meet the urgent need to implement the responsibility system.(People's Daily, 28 July 2005:2) The document stipulates three main requirements:

1. To strengthen the law enforcement basis, i.e., to refine and make clear relevant laws and regulations as well as the 'three fixes' (san ding) ${ }^{15}$ regulations which are used for administrative law enforcement.

2. To break up law enforcement authorities, i.e., to allocate statutory authorities to actual law enforcement institutions and posts.

3. To set out law enforcement responsibility, i.e., to determine the responsibilities of law enforcers at different departments or posts and to determine the categories and contents of responsibilities that law enforcers should assume.(People's Daily, 28 July 2005:1) 
To enhance the implementation of the law enforcement responsibility, an assessment mechanism has been established. The Opinion also provides clear details on how to investigate and deal with illegal or improper law enforcement undertakings. Punishment is to be imposed too for administrative omissions.

\section{Administrative Transparency}

Transparency plays a vital role in administration in accordance with law; it is not only a requirement from the WTO, but was also called for during the SARS period. As a result, the new Regulations on Public Health Emergencies were enacted in May 2003 (People's Daily, 13 May 2003:8). These stipulate that any individual or organization has the right to report emergencies and to accuse governments of not performing their duties according to law. The Regulations have for the first time established the freedom of information system at the governmental level. The 2004 Implementation Program of Comprehensively Pushing forward Administration in Accordance with Law requires the openness of government information. Accordingly, administrative bodies are required to release government information except for State secrets, legally protected commercial secrets and matters concerning personal privacy. The public has the right to consult the released information on the basis of the conditions set out by the government. (2004 Implementation Program) Among the local governments, the Government of Guangzhou was the first to adopt the freedom of information regulations in early 2003. The rapid development of government internet websites has enhanced government transparency. As of July 2005, there were more than 10,000 government websites registered under gov.cn (People's Daily, 28 July 2005:10).

There was an interesting case recently in Shanghai regarding access to government information. Dong Ming, a 70-year-old woman, sued the Housing and Land Administration Bureau of Xuhui District after she was refused access to archived documents pertaining to the villa she used to live in. The legal basis of her case is the Provisions of the Shanghai Municipality on the Openness of Government Information, which took effect on 1 May 2004. According to Dong, her father bought the villa in 1947 , but her family was expelled from it in 1968. The Bureau said that, based on a 1998 regulation, only the owner of the villa could read the original documents of the property (Cao 2004). Since it is the first case regarding access to government information, it attracted a high level of 
attention within China, in particular from the legal sphere. The case has been discussed in the mass media as well as in law journals. ${ }^{16}$

It is suggested that the process of administrative transparency and openness should be added to some major laws that are of vital interest to the Chinese people, such as the Law on Government Procurement, the Agricultural Law and the Law on Production Safety. The 1998 revised Law on Land Management does not provide an open and transparent procedure for land appropriation (tudi zhengyong). This affects the interests of peasants who are only informed of the government decision after it has been taken (Wen 2004(2):3-4). Another problem in administrative transparency is related to the implementation of the Law of Confidentiality. ${ }^{17}$ According to that law, regulations and laws related to national security and interest are deemed State secrets; indeed, the law sets out seven categories which are regarded as confidential and to be kept from the public. However, the relevant provisions in that law are not detailed enough; consequently a large amount of government information which is open to the public in other countries is kept secret from the Chinese public. For example, the Regulations on State Confidentiality and Scope of Confidentiality in Auditing Work, which was jointly issued by the State Audit Administration and the State Confidentiality Bureau in June 1996, classifies 'auditing investigations and results regarding leading cadres at the provincial level' as a confidential item (Wen 2004(2):11). It is also suggested that 'administration openness' (zhengwu gongkai) should be incorporated into the Chinese Constitution so that it can bind the ruling party and change the governance method (Wen 2004(6):38-40). On the other hand, since there is no law on administrative transparency at the national level, it is still unclear to what extent administrative information should be open to the public, who should take the responsibility for concealing the information, and who can exercise the power of supervision or make amendments (Yue 2004:1). It is reported that the Regulations on Government Information Openness will be published in the near future and that the right of citizens to government information will be guaranteed (People's Daily, 28 July 2005:10) ${ }^{18}$. Although these new Regulations will be welcomed generally, many government departments and local governments are still not accustomed to this new practice of administration.

It is worth mentioning the 'Audit Storm' which took place in June 2004. Li Jinhua, Chief of the State Audit Administration, reported to the NPC regarding the implementation of the 2003 central budget and other financial revenues and expenses. His report revealed illegal activities by 
some government departments and officials. No matter whether these illegal activities are linked to corruption or embezzlement, they are all related to the compliance of the law in administration. According to the plan of the State Audit Administration, all the auditing results except for state or commercial secrets have to be accessible to the public by 2007 (Shen 2004). Independent auditing in China is not an easy job. The State Audit Administration was only established in September 1983 and being a quasi-ministerial level department under the State Council, it is not regarded highly by other government departments. The 2004 Audit Report created resentment from relevant departments and encountered difficulties in tackling the illegal activities. However, the audit process assists in the realization of law-based administration as well as providing administrative transparency.

Transparency is also a response to the development of the internet. Formerly, the government was able to monopolize and control the flow of information, but with the development of the internet, the public information platform has become much broader. Government control is becoming extremely difficult, thus making transparency an inevitable choice. As of 2004, the number of internet users in China was 94 million (Shi and Wang 2005:13). The internet has therefore become a new challenge to the CCP as the sole ruling party in China.

\section{The Anti-Corruption Campaign}

Corruption can cause social instability. More importantly, it can cause people to question the fairness of the $\mathrm{CCP}$ and even to challenge its legitimacy to rule the country. It is imperative therefore for the CCP to launch an anti-corruption campaign. It should be noted that before the economic reform, corruption was not a big problem. However, the emphasis on economic development in past decades has encouraged the spread of corruption in China in various forms, giving rise to what has been called 'systemic corruption'(Klitgaard 2000:2-5). Facing such a serious problem, China has to use the law to crack down on corruption, particularly after it had introduced the rule of law. The CCP has also come to a realization that the use of ideology to crack down on corruption is ineffective, as revealed in the so-called 'three stresses' (san jiang) campaign. ${ }^{19}$

Realistically, it is impossible for China to completely eliminate corruption; what it can do though is to curb its growth. ${ }^{20}$ One reason for this lies in the fact that China is a one-party country. As long as the power of 
the CCP is not effectively checked and supervised, such power can still give rise to corruption. Anti-corruption campaigns have been carried out in China from time to time since the founding of the PRC, particularly after the economic reforms. However, after more than 20 years of reform, the situation has become more severe. The reason is simple: corruption is inextricably linked to power. When power is unrestricted, corruption breeds quickly (Li 2000:13). A robust system of checks and balances needs to be established urgently. As has been rightly pointed out, 'the more checks and balances exist within a society, and the more strong institutions are in place to protect such checks and balances, the fewer opportunities there may be for corrupt practices which remain unchecked or unpunished' (Ibrahim 1997:467). A number of adopted measures to fight corruption are detailed below.

\section{Recent Measures with Economic Leverage}

Economic sanctions are necessary for a crackdown on corruption since economic benefits provide the original momentum for the spread of corruption. The State Audit Administration has prepared a plan to audit all government and Party officials, including those at ministerial level, when they leave their posts. According to the plan, the auditing system focuses on two areas: (a) an investigation to determine whether or not the official has ever violated the country's financial regulations and rules and (b) an attempt to establish whether or not the official has fulfilled his/her duties. One of the aims is to help uncover clues of corruption which will serve as a warning to officials who are still at their posts. While the problem of corruption cannot be solved by this post-departure audit, given that there are a number of difficulties in implementation, the audit system can still play an important part in the anti-corruption campaign (Liu 2000). ${ }^{21}$ It is reported that over the past two years, the auditing process has accomplished its task and discovered that three deputy-ministerial level officials had been involved in corrupt practices (Legal Daily, 11 July 2005).

The other economic measure is the 'two separate lines in revenue and expenditure' (shouzhi liangtiao xian). The main provisions of this system are as follows:

1. All items and standards for fees must be approved by the State Council or the government above the provincial level; no unauthorized items for fees shall be made, and the scope of fee-collection should not be expanded.

2. When charging fees or fines, the unified receipts printed by the 
central or provincial financial departments should be used, and certificates of identify should be shown.

3. The collection of fees and fines should be made strictly in accordance with the law, and fine and fee collection should be administered separately.

4. The opening of bank accounts should be approved by finance departments and the people's bank. No bank account should be opened without authorization and no 'small treasuries' (xiaojinku) should be established in private.

5. All administrative fees and revenue based on fines should be handed over to the national treasury; no amount should be taken in secret.

6. When arranging the budgets for the law enforcement departments, the finance departments should separate the hand-over administrative fees and revenue from fines from their expenditure, and the administrative fees should be used with priority given to the necessary expenditure of any relevant work ('Circular of the National Audit Office' 1999:1216-18).

It is obviously another important measure to prevent and control corruption at the source.

\section{Administrative Measures}

The recent measures to combat corruption in China include the reform of personnel and the introduction of a rotation (lun gan) mechanism in the civil service. In 1996 the Ministry of Personnel prepared the Provisional Measures of Position Change among Civil Servants in accordance with the Regulations of State Civil Servants. Based on these measures, from 1996 to the end of 1998, 400,000 civil servants in 27 provinces undertook the rotation. The mechanism has proved to be effective in reinforcing the supervision of civil servants, in raising morale and efficiency, and in improving the integrity of governmental bodies. It is an important measure to prevent the spread of corruption.

The Reform Program to Deepen the Cadre System of Personnel in 2000 sets out the following measures:

1. To reinforce the process of open selection of leading cadres and to allow official positions to be awarded through competition;

2. To introduce the 'open show' system (gongshi zhi) for leading cadres before they take up their positions. This is designed to put in the public domain the personal details of the appointees for comment and evaluation. The appointment will take effect after a period of 
time provided that there is no negative feedback from the public.

3. To take various measures to resolve the problem of cadres stepping down.

4. To develop cadre work exchanges.

5. To reinforce the supervision of selecting and appointing leading cadres and other cadres.(People's Daily,21 August 2000; Legal Daily, 23 August 2000)

It should be pointed out that though the above reform of the personnel system is necessary, other supplementary measures should also be introduced, such as adequate pay for civil servants and improving the civil service recruitment system. Transparency International's Corruption Perceptions Index and Bribe Payers Index show that bribe-taking in many developing countries is extensive, primarily because of low public salaries, and senior public officials' and politicians' de facto immunity from prosecution (Pope and Vogl 2000:6). The professionalization of the civil service is thus a key element to curb official corruption. Accordingly, high-ranking governmental officials should be appointed through the open recruitment system rather than by the CCP Department of Organization whose operation is often shrouded in secrecy.

After the change of the Chinese leadership, the CCP has tightened up its anti-corruption campaign. Based on the requirement put forward in the CCP Decision on Strengthening the Construction of the Governing Capability of the Party, the CCP issued the Implementation Program on the Establishment of the System of Punishment and Prevention of Corruption in early 2005. It attempts to establish a preventive system to curb rampant corruption in China and targets eight areas:

1. To implement the Law on Administrative Licensing and reform the administrative examination and approval system.

2. To deepen the reform of financial management system and to realize the goal of 'two separate lines in revenue and expenditure'.

3. To implement the State Council Decision on the Reform of the Investment System and to strengthen the supervision of governmental investments.

4. To enhance the reform of the cadre/ personnel system and to establish a supervisory mechanism for cadre selection and appointment.

5. To undertake the reform of the supervision system in accordance with the CCP (Trial) Regulations on the Intra-Party Supervision.

6. To continue the reform of financial enterprises and improve supervision of the banking system. 
7. To enhance the judicial reform and strengthen the judicial supervision.

8. To manage and supervise various social organizations, including professional organizations and intermediary agencies (Liaowang News Weekly, January 2005).

Despite all these new measures and initiatives, corruption remains a serious problem in Chinese society. The recent cases reveal that more and more corrupt officials fled overseas before their criminal activities could be unearthed. It is reported that in Fujian Province alone, 69 corrupt officials fled abroad during the first half year of 2004 .

The year of 2006 witnessed the downfall of a number of high-ranking officials including Chen Liangyu, former Party Secretary of Shanghai, Liu Zhihua, former Deputy Mayor of Beijing and Qiu Xiaohua, former Head of the National Statistics Bureau. In a speech given to the plenary session of the CCP Central Commission for Discipline Inspection in January 2007, Hu Jintao stressed that the anti-corruption campaign should be developed on four major fronts: to step up ethics education, to keep up the momentum of the campaign by routing out key offenses and high-level suspects, to address the problems that pose a great threat to the public interest, and to mend the official system and its procedures (China Daily, 10 January 2007).

\section{Judicial Remedies}

The Law on Administrative Review makes provision whereby any citizen who feels that his or her rights have been infringed by a decision from a government organ, has the right to request an administrative review. However, since administrative review is usually carried out by the same administrative organ that made the original decision, this kind of administrative remedy is insufficient; there is a need for recourse to other channels. The 1989 Law on Administrative Litigation for the first time set out the detailed standards to determine which administrative activities are to be considered legal or illegal. Chinese courts have the right to repeal illegal administrative activities. It is reported that since the implementation of the Administrative Litigation Law, and as of April 2004, courts throughout the country had accepted and handled more than 910,000 'min gao guan' (ordinary people suing governmental officials) cases of first instance, covering more than 50 different administrative areas. For closed cases, the rate for plaintiffs wining the 
case is about 30 percent. ${ }^{22}$ Despite the low success rate, more and more ordinary citizens are resorting to the judicial channel for legal remedy. It shows remarkable progress that Chinese peasants have now learnt how to use administrative litigation against local governments, usually collectively (Yuen 2005:24-49).

It may be recalled that 15 years ago, when the Law on Administrative Litigation was drafted, some government departments objected to the use of such terms as 'defendant' and 'plaintiff' because in their minds a government could not be a 'defendant'. They believed that if the government and ordinary people were to sit before the court on an equal footing, the authority of the government would be undermined (Wu 2004:6). However, after the implementation of this law, the mindset of the government departments as well as government officials began to change. In the case of the Inner Mongolia Jinsui Food Company v. the Trademark Bureau of the State Administration for Industry and Commerce in 2004, Fan Hanyun, executive Deputy Director of that bureau, as representative of the defendant, appeared at the court. Up until then, relevant departments of the central government only appointed an ordinary staff member and a lawyer to be present at the court hearing (China Daily, 2 April 2004). This indicates the sea-change in the attitude of the government departments from passive to proactive regarding administrative litigation, which is linked to the development of the rule-of-law process in China. It can only be hoped that the previous three common 'fears' in administrative cases may eventually disappear: (a) ordinary people being afraid to sue government officials for fear of reprisals; (b) administrative bodies being reluctant to respond to the lawsuits for fear of losing face if they lose the case; and (c) courts being reluctant to hear the administrative cases for fear of offending the administrative bodies concerned (Wang 1998).

However, some of the provisions in the Law on Administrative Litigation are out of date and in need of urgent revision. As suggested, there are at least five areas that need to be revised:

1. expansion of the scope of administrative litigation and removal of the exclusion of entities in its scope;

2. expansion of the qualification of plaintiffs;

3. safeguarding the right to lawsuit of the interested parties;

4. establishment of the administrative court; and

5. strengthening of the imposition of legal liability on the administrative chief. ${ }^{23}$ 
The revision of this law has been incorporated in the Five-Year Legislative Plan of the 10th NPC Standing Committee. In the implementation of the Administrative Litigation Law, there are also difficulties for ordinary citizens to bring government departments and/or officials to court. A paper published in a recent issue of The China Journal examined administrative litigation in rural China and found that:

To offset the many advantages enjoyed by the government offices that are sued, including the propensity of judges and other officials to protect one another, plaintiffs often need to secure support from advocates from officialdom or in the media. Collective action, or the threat of it, can also increase the likelihood of winning (O'Brien and Lianjiang 2004:93).

The 1994 State Compensation Law, ${ }^{24}$ through its establishment of a compensation system for victims, is a major supplement to the Law on Administrative Litigation. It provides that victims who have suffered damages caused by State organs or their personnel have the right to claim compensation from the State. It establishes two categories of compensation and their remit: (a) administrative compensation applicable to illegal activities committed by State organs or their personnel and (b) criminal compensation applicable to illegal activities undertaken by public security departments, judicial bodies, or prison management departments. To cite a typical case that took place on 9 April 2001, 25 repatriated people were burnt to death in a minibus, on the way from Haifen to Guangzhou in Guangdong Province. The families of 11 victims were not satisfied with the treatment they had received after the accident and decided to sue the Shanwei Bureau of Civil Affairs in January 2003. On 18 April 2004, the court of first instance ruled that the Shanwei Bureau had to pay compensation for the amount of $187,000 \mathrm{RMB}$ to each of the victims' families. The Intermediate Court of Shanwei upheld the above ruling in the appeal case afterwards. ${ }^{25}$

As of November 2004, from the effective date of the Law in 1995, procurators at all levels throughout the country registered and handled 7,823 compensation cases. Of these, 3,167 cases involving compensation for more than 58 million RMB. ${ }^{26}$ In order to improve the State compensation system, the 2004 Implementation Program of Comprehensively Pushing forward Administration in Accordance with the Law requires the administrative compensation to be undertaken in strict accordance with the Measures on the Management of State Compensation Funds. This is to safeguard the right of citizens, legal representatives or other organizations to obtain compensation under the law (2004 Implementation Program). 
Finally, it is worth mentioning the Decision on Certain Issues of Handling Administrative Cases of International Trade, which was issued by the Supreme Court in August 2002, and which concerns foreign investors and entrepreneurs. It is the first such regulation relating to handling trade cases in line with the WTO regulations. According to Article 10 of this regulation, foreigners and foreign entities have the same litigation rights as Chinese citizens and entities in administrative cases relating to international trade. However, if a certain foreign country sets limits against Chinese citizens as to the same right, then the reciprocity principle applies. In fact, the regulation embodies the rule of judicial review required by the WTO law. In China's legal framework, judicial review refers to administrative litigation and administrative trial. Under the new regulation, any person, whether foreign or local, has the right to request a review of certain administrative activities through litigation. The relevant court will examine the case by looking into seven aspects: whether the evidence is genuine and adequate; whether laws and regulations are applied correctly; whether there is a breach of statutory procedure; whether there is ultra vires; whether there is an abuse of power; whether administrative punishment is obviously unfair; and whether there is omission and delay of performing statutory duties. ${ }^{27}$ The regulation assists Chinese courts in supervising the conduct of governmental bodies involved in international trade administration (China Daily, 30 August 2002). While such a judicial review is limited to cases relating to international trade, it will be a good indication as to how the Chinese courts function to curb government abuses and illegal practices.

It is indicative that more and more social upheavals have occurred in recent years due to official corruption and/or social injustice and inequality. Therefore remedies are even more important to maintain the stability of the Chinese society, particularly when the Chinese leadership is calling for the building of a harmonious society.

\section{Rule of Law: A New Communist Ideology?}

In 1991, the Party Central Committee stressed that:

In the new historic period, one of the most important areas for the Party to lead the State affairs is to turn the Party's policy into State will, then into behavioural norms with universal binding force for the whole society through the State legislature and in accordance with legal procedures. The Party leads the people to make the constitution and law and the Party leads the people to comply with and implement the constitution and law. This is the important political principle in our legal construction and also an important guarantee for the continuing development of the legal construction. ${ }^{28}$ 
This paragraph is open to various interpretations. First, it indicates that the Party has realized the importance of the law and would like to rely on it for State governance and social control. The Party has decided to use the law to implement its policy, instead of using internal documents as was previously practiced. This may be a positive step towards the realization of the rule of law in China. Second, it can be interpreted as instrumentalism in its use of the law as a social control instrument: it emphasizes the leadership of the Party, rather than the people, in society. However, through legal procedures, when the Party policy is wrong, then there will be bad laws which can only damage public attitudes toward the rule of law. Furthermore we need to be aware that wrong policies often occur often in history.

Third, although the era has now passed when Party policy was considered law, the Party still exerts a significant influence on the Chinese legal system, particularly as reflected in the Chinese Constitution. It is doubtful whether 'red-dotted documents' that set themselves above the law can now be considered things of the past. A recent case illustrates the point. Towards the end of 2003, the Legal and Political Committee of Hebei Province issued a Decision on Creating a Better Environment for Perfecting the Socialist Market Economy System. This effectively decriminalized private entrepreneurs who had committed crimes when they started up their businesses. This document has been criticized by the Party department as encouraging illegal and/or criminal activities and interfering in normal judicial procedures. ${ }^{29}$

Government policy continues to emerge in legislation, as it did in the past, and policy jargon is also evident occasionally, in phrases like 'the state encourages, or supports, or grants'. The State Constitution itself is used by the Party as a policy document (Cai and Liu 2000:91). In contradistinction to constitutionalism, the Chinese Constitution contains provisions regarding the socialist economic and political systems. Recently, there has been an argument that the Party's general policy is the soul of the law and that the law is the reflection of the Party's general policy, instead of the previous perspective that policy is the soul of law and law reflects policy (Zhou and Deng 2002:136). Reliance on policy is basically a manifestation of the rule of man and the realization of the rule of law requires that state law should be above the Party policy. Optimistically, we predict that in the process of the rule of law, policy will be gradually subordinated to the constitutional norms, rather than the Constitution continuing to be a dependent on Party policy, as Jiang Zemin once pledged that '[w]e should never treat the Party as the gov- 
ernment, or as the law. I think we must abide by the guideline of the rule of law' (People's Daily, 27 September 1989). ${ }^{30}$ It is also recalled that Peng Zhen once responded to the question as to the superiority of law to the Party. He maintained that the law is superior to the Party Committee and the Party Secretary; and that if there is inconsistency, the law should be abided by (Selected Works of Peng Zhen 1991:389).

There are a number of provisions in the 1982 Constitution that aim to reduce the Party control of the legal system, such as the provision that:

All state organs, the armed forces, all political parties and public organizations and all enterprises and undertakings must abide by the Constitution and the law. All acts in violation of the Constitution and the law must be looked into. No organization or individual may enjoy the privilege of being above the Constitution and the law.

Another provision states that:

The people's courts shall, in accordance with the law, exercise judicial power independently and are not subject to interference by administrative organs, public organizations or individuals'..$^{31}$

The above provisions seem to conflict with other provisions contained in the same Constitution, such as:

[The Party] must see to it that the legislative, judicial and administrative organs of the State and the economic, cultural and people's organizations work actively and with initiative, independently, responsibly and in harmony ... If the party is subject to the State's laws, it cannot legitimately supervise the State as a lawmaking body... When contradictions between the Party policy and law exist, it is not clear whether such contradictions will be resolved by following the Party policy, the law, or handling them on a case-by-case basis (Folsom et al.1992:91-2).

Under the constitutional 'four fundamental principles', the supreme authority of the CCP cannot be fully curbed and supervised by the law, despite the relevant constitutional stipulations mentioned above. For the Party, the basic line is the maintenance of its leadership over the legal developments and legal reform in China. As is commonly said in China, the rule of law is the unity of the Party leadership with the mastery of the people. Law is the reflection of the Party's position and people's will, so that the rule of law is an important mode of Party leadership with the mastery of the people. It is also the best mode to integrate the insistence of the Party leadership with the enhancement of the people's mastery (Li 2003:9). It is reported that Zhang Yinghong, a cadre working at the department of Party organization of Hunan Province, published an essay 
entitled 'Political-Legal Committee hampers judicial independence' on a Chinese website in July 2003. He was then criticized heavily by Zhou Yongkang, Vice Secretary of the Central Political-Legal Committee and Minister of Public Security, who said that the article had caused a very negative impact overseas. As a result, Zhang Yinghong was forced to leave his post (Ming Pao, 9 September 2003). This incident indicates that the Party will not tolerate any challenge to its leadership over the law. That is why it is argued that it is the Party's economic agenda, rather than its political agenda, that requires the rule of law (Giri 1998:266).

It is proposed that since the governance of the state is now in accordance with the law, the governance of the Party should also be in accordance with the law. However, the term 'governing the Party in accordance with law' (yifa zhidang) has been rejected by the CCP. Instead the Party has accepted a modified term 'ruling in accordance with the law' (yifa zhizheng). Does this rejection imply that the Party is still above the law? The current picture in China is mixed: it contains rule-of-law elements and also rule-of-Party elements. While the Party has undoubtedly exerted a great influence over the legal system, we should realize that with the economic reform and the development of the legal system per se, such influence may be weakened, particularly when the 'rule of law' has been enshrined in the Constitution. The other point we have to bear in mind is the paradox that lies at the heart of China's current legal reform, i.e., the rule-of-law process was initiated by the CCP but the CCP itself could become the target to be trimmed and constrained as a result of such reform. In this sense, the Party may not survive the legal reform if it does not reform itself in correspondence with the legal developments.

A relevant positive endeavour recently made by the CCP is its requirement that 'the Party should govern the Party' (dang yao guan dang). Law is regarded as a useful tool in this respect. As early as 1986, the CCP Central Committee called for its organizations and members at all levels to study, understand and observe the Constitution and laws. 'No Party organizations and members, from the Central Committee down to the grass roots, are allowed to act in contravention of the Constitution and laws'('Circular of the CCP Central Committee' 1991:530). Based on this, intra-Party democracy (dang nei minzu) should be improved, and through it, the leading style of the Party will be transformed from 'rule of man' to 'rule of law' so that it can strengthen the Party's leading and ruling capacity (Lin 2002:260-2). The question here is how, and to what extent, the Party can be effectively self-disciplined, without a checks- 
and-balances force existing within Chinese society? It is disappointing to note that the corruption of Party officials shows no sign of abating, despite the Party issuing numerous documents designed to prevent and curb corruption.

\section{Conclusion}

Law-based administration is now a requirement in China after its admission into the WTO; it is also a prerequisite for the development of a market economy. The transformation from a management-type government to a service-type government is also linked to the policy of the Fourth Generation leadership. It is worth remembering that the government led by $\mathrm{Hu}$ Jintao and Wen Jiabao has promised that its government will be more attuned to the people's needs (Pomfret 2003: A18). However, the question of whether the 2004 Implementation Program as well as the Administrative Licensing Law can be effectively implemented remains unanswered. The main problem is whether the Communist Party and the government officials will be able and willing to comply fully with the laws. As pointed out, any failure on the part of the government to observe the law will seriously undermine the whole concept of the rule of law (Jiang 1995:74). China may have realized that it will take a long time to reach the goals of law-based administration. Clearly, the CCP does wish that '[ $\mathrm{t}$ ]he legal system could be strengthened in a number of ways that do not directly threaten the Party but rather further its self-professed goals to rationalize governance, increase government efficiency, rein in local officials, and root out corruption' (Peerenboom 2002:74).

On the other hand, China is in a transitional period of social restructuring, in which 'rule of man' and 'rule of law', 'rule by law' and 'rule of law' coexist. The current legal reform in China can be characterized as 'rule of the Party by law', which stands somewhere in the middle, departing from the 'rule of man', but not yet reaching the realm of the 'rule of law'. It is perhaps inappropriate to use the standards of a mature legislative society to measure China's legal development. Although the CCP has imposed some negative constraints on the development of the Chinese legal system, it is admitted that the recent achievements in China's legal reform should be attributed to the efforts made by the Party, particularly when we recall that in the earlier times such as in Mao's era, the CCP rejected outright the concept of the rule of law. It is interesting to note that according to some observations, the number of 
Chinese leaders with a training in law has increased; and the number of full members with law degrees have risen from three ( 2 percent) to eight (4 percent) between the last two CCP Central Committees ( $\mathrm{Li}$ and White 2003:581). ${ }^{32}$ The course set towards the rule of law is thus irreversible, just as China's economic reform has proved to be since 1978.

Zou Keyuan is Harris Professor of International Law, Lancashire Law School, University of Central Lancashire, United Kingdom.

\section{NOTES}

1 This paper is based on a lecture given at the Copenhagen Business School on 2 May 2006. I am very grateful to Professor Kjeld Erik Brødsgaard his kindness in inviting me to the School for an academic visit.

2 It stipulates that 'the People's Republic of China implements law to govern the State and construct the socialist country with the rule of law'.

3 Text is available at: http:/ / news.xinhuanet.com/lianzheng/2005-08/10/content_ 3333987.htm (accessed 17 August 2005).

4 For details on the significance of this Decision, see Yingyi and Jinglian 2003:35-8.

5 For example, in April 1993, the Senior Lecturers' Team for High-Ranking Officials to Learn Law was set up for leading cadres at various levels. The team consisted of law professors and legal officials above the bureau level: see $\mathrm{Xu}$ and Yu 1998:211. During the whole of 2000, a number of teachers in the China University of Political Science and Law conducted a so-called 'ten thousand li' lecture tour covering 100 cities and towns in 32 provinces: see Zhao 2000:154-5

6 Since 1994, CCP has invited legal experts to Zhongnanhai to give more than 10 seminars. Since June 1999, the NPC Standing Committee has held regular seminars on law and as of the end of 2001, 24 lectures had been given by legal experts.

7 For details, see Zou 2004:99-122.

8 Art. 2 of the Administrative Licensing Law.

9 Art. 5 of the Administrative Licensing Law.

10 See Art. 15 of the Administrative Licensing Law.

11 'New Law Approved to Improve China's Civil Servant System', 27 April 2005. Accessed 28 June 2006 at: http:/ / www.chinalaw.gov.cn/jsp/contentpub/ browser/ contentpro.jsp?contentid $=$ co2036791762

12 For details, see 'Two Responsible Persons for the Miyun Stampede Accident Were Tried and the Court Hearing Lasted for Seven Hours', New Beijing Daily, 14 October 2004. Accessed 14 October 2004 at: http://www.people.com.cn/GB/ shehui/1063/2917898.html

13 See 'State Council Dealt with the Songhua River Pollution Caused by the Explosion Incident of the Jilin Petroleum Chemical Company', 24 November 2006. Accessed 24 November 2006 at: http:/ / politics.people.com.cn/GB/1026/5085239.html

14 Text is available at: http:/ / www.law-lib.com/law/law_view.asp?id=91802 (accessed 22 July 2005).

15 The so-called 'three fixes' refers to a plan whereby a governmental department can know what its responsibilities are, how many people it should have, and how many official positions it can assign.

16 For example, Zou Rong, a professor from East China University of Politics and Law, 
said that 'the Bureau should provide the information to Dong. What she requested is actually archives that are more than 30 years old, which should be open to the public according to the law.' However, another legal scholar does not think that the Court should support Dong since documents concerning housing registry are regarded as personal privacy so that the refusal by the Bureau was right. See Liu Feiyu 2005:122-8.

17 It is adopted in September 1988 and came into force on 1 May 1989. Text is available at: http:/ / www.sdca.gov.cn/anquan/baomifa.htm (accessed 10 August 2005). The Regulations are expected to be promulgated in 2007 since the draft has been adopted by the standing meeting of the State Council in January 2007, see People's Daily, 18 January 2007:1.

19 The 'three stresses' campaign was initiated in 1999 and continued in 2000. It was an effort to revitalize party identity, but could not achieve its goal. See Zheng 2000:27.

20 Klitgaard asserts that it is impossible to eliminate corruption entirely, that the best any government can do is balance various considerations and determine its own 'optimal level of corruption'. See Klitgaard 1988:24.

21 See Liu 2000. It is reported that since April 2000, the State Audit Administration has audited the leaders of six major financial institutions when they left their posts. See Wang 2000.

22 See 'The Winning Rate for Ordinary People to Sue the Officials in China is About $30 \%$ and the Revision of the Administrative Litigation Law Needs Five Breakthroughs', 6 April 2004, Accessed 6 April 2004 at: http:/ / www.hsm.com.cn/node2/node116/ node275/node276/userobject6ai162926.html See 'The Winning Rate for Ordinary People to Sue the Officials in China is about 30\% and the Revision of the Administrative Litigation Law Needs Five Breakthroughs', 6 April 2004, Accessed April 2004 at: http://www.hsm.com.cn/node2/node116/ node275/node276/userobject6ai162926.html

Text is reprinted in Peng 1998:50-6. It came into force on 1 January 1995.

25 For details, see '25 People Burnt to Death in a Repatriate Bus in Guangdong and Victim Families Got State Compensation', 18 November 2004. Accessed 18 November 2004 at: http://www.peacehall.com/news/gb/china/2004/11/200411181354.shtml

26 See 'Supreme Procurator Explores the Reform on State Compensation Law, Compensation of More than 58 Million for 10 Years of the Law Implementation', New Beijing Daily (in Chinese), 3 January 2005. Accessed 3 January 2005 at: http:/ / www. people.com.cn/GB/14576/14957/3094389.html

27 Art. 6 of the Regulation. Also see 'Supreme Court Determines the Review Criteria for Administrative Cases Relating to International Trade'. Accessed 7 September 2002 at: http:/ / www.chinacourt.org/public/detail.php?id=9779

See 'Handling Well Six Relationships in Local Legislation - speech made by Jiang Chunyun, NPC Vice-Chairman at the seminar on local legislation in Shenzhen'. Accessed 16 September 2003 at: http://www.npcnews.com.cn/gb/paper7/26/ class000700002/hwz228320.htm

29 See 'Red-Dotted Document Pardoned Crimes of Private Enterprises and the CCP Hopes to Stop Capital Flow Overseas'. Accessed 11 February 2004 at: http:/ / www. lundian.com/forum/view.shtml?p=PS200402091401001017\&l=chinese

30 Cited in Liao 1999:5.

31 Articles 5 and 126 of the Chinese Constitution.

32 Caution should be taken when counting the number of law degrees, since in China graduates trained in political science, public administration, international relations and sociology are all granted law degrees in addition to those trained in law. 


\section{REFERENCES}

'25 People Burnt to Death in a Repatriate Bus in Guangdong and Victim Families Got State Compensation', 18 November 2004. Accessed 18 November 2004 at: http:/ / www.peacehall.com/news/gb/china/2004/11/200411181354.shtml

'Banking Supervisory Committee: Five Big Administrative Punishment May Be Subject to Hearing', International Financial Daily (in Chinese), 4 January 2005.

Cai Dingjian and Liu Dan 2000. 'From Policy Society to Rule of Law Society'. In Huang Zhiying (ed.), The Road to the China's Rule of Law. Beijing: Peking University Press, 2000: 91.

Cao Li 2004. 'Lawsuit over Access to Housing Archives'. China Daily, 5 July 2004.

Cheng Jie, 'Prevention and Treatment of SARS Needs the Exercise of Power by People's Congresses'. Accessed 26 July 2003 at: http:/ / www.iolaw.org.cn/feidian/ shownews.asp?id=790

'Circular of the CCP Central Committee on Resolutely Upholding the Socialist Legal System Throughout the Party' 1991. In Research Department of Party Literature, Central Committee of the Chinese Communist Party (ed.), Major Documents of the People's Republic of China - Selected Important Documents since the Third Plenary of the Eleventh Central Committee of the Communist Party of China (December 1978 - November 1989). Beijing: Foreign Languages Press 1991: 530.

Circular of the National Audit Office Concerning Further Implementation of the Regulations on 'Separation between Revenue and Expenditure' 1999. Gazette of the State Council of the People's Republic of China 28: 1216-18

Giri Deshingkar 1998. 'Rule of Law vs. Rule of Man: Contradictory Pulls in China'. In Satish Saberwal and Heiko Sievers (eds), Rules, Laws, Constitutions. New Delhi: Sage Publications 1998: 266.

Folsom, Ralph H., John H. Minan and Lee Ann Otto 1992. Law and Politics in the People's Republic of China. St. Paul, Minn.: West Publishing Co.: 91-2.

'Handling Well Six Relationships in Local Legislation - speech made by Jiang Chunyun, NPC Vice-Chairman at the seminar on local legislation in Shenzhen', Accessed 16 September 2003 at: http:/ / www.npcnews.com.cn/gb/paper7/26/class000700002/ hwz228320.htm.

Huang Haixia and Han Bingjie, 'Self-Revolution of the Government', Liaowang News Weekly, 14 June 2004, No. 24. Accessed 6 July 2004 at: http:/ / www1.people.com. cn/GB/shehui/1063/2602969.html

Ibrahim Shihata 1997. 'Corruption - A General Review with an Emphasis on the Role of the World Bank'. Dickinson Journal of International Law (15): 467.

Jiang Ping 1995. 'Chinese Legal Reform: Achievements, Problems and Prospects'. Journal of Chinese Law 9 (1995): 74.

Klitgaard, R. 1988. Controlling Corruption. Berkeley: University of California Press: 24.

- 2000. 'Subverting Corruption', Finance \& Development, June 2000

'Law of Confidentiality'. Accessed 10 August 2005 at: http://www.sdca.gov.cn/ anquan/baomifa.htm.

'Law on Civil Servants'. Accessed 22 July 2005 at: http://www.law-lib.com/law/ law_view.asp?id=91802

Liao Susheng 1999. 'Brief Comments on Comrade Jiang Zemin's Thoughts on Governing the State by Law'. Law Science 6 (1999): 5.

Li Cheng and Lynn White 2003. 'The Sixteenth Central Committee of the Chinese Communist Party: Hu Gets What?'. Asian Survey 43(4): 581.

Liu Feiyu 2005. 'Case Study: A Link between Publication of Administrative Information and the Protection of Personal Data'. Legal Science Monthly 4(2005): 122-8. 
Liu Weiling, 'New Move to Fight Graft', China Daily, 21 August 2000

Li Liangdong, 'Deepening Theoretical Perception and Enhancing Practical Development', People's Daily, 25 November 2003.

Lin Shangli 2002. Democracy within the Party: Theory and Practice of the Chinese Communist Party. Shanghai: Shanghai Academy of Social Sciences Press: 260-2.

Li Rongxia. 'Inflicting Severe Punishment on Corruption'. Beijing Review, 22 May 2000.

Meng Yan. 'Law Alters National Licensing Standards'. China Daily, 29 June 2004.

'New Law Approved to Improve China's Civil Servant System'. 27 April 2005. Accessed 28 June 2006 at: http:/ / www.chinalaw.gov.cn/jsp/contentpub/ browser/ contentpro.jsp? contentid $=$ co2036791762

O'Brien, Kevin J. and Lianjiang Li 2004. 'Suing the Local State: Administrative Litigation in Rural China', China Journal, 2004 (51): 93.

Peerenboom, Randall 2002. China's Long March toward Rule of Law. Cambridge: Cambridge University Press: 226.

- 2006. 'A Government of Laws: Democracy, Rule of Law, and Administrative Law Reform in China'. In Suisheng Zhao (ed.), Debating Political Reform in China: Rule of Law vs. Democratization. Armonk, New York: M.E. Sharpe 2006: 66-7.

Peng Liming (ed.) 1998. Compendium of the Existing Laws of the People's Republic of China. Beijing: China Construction Materials Industry Publisher 1: 50-6.

Pope, Jeremy and Frank Vogl 2000. 'Making Anticorruption Agencies More Effective'. Finance \& Development, 37(2): 6.

Pomfret, John. 'China's Slow Reaction to Fast-Moving Illness, Fearing Loss of Control, Beijing Stonewalled'. Washington Post, 3 April 2003.

'The 2004 Implementing Program'. Accessed 17 August 2005 at: http:/ / news.xinhuanet. com/lianzheng/2005-08/10/content_3333987.htm

'Quarterly Chronicle and Documentation' 1979. The China Quarterly 77 (March): 172

Qian, Yingyi and Jinglian Wu 2003. 'China's Transition to a Market Economy: How Far Across the River?'. In Nicholas C. Hope, Dennis Tao Yang and Mu Yang Li (eds). How Far Across the River? Chinese Policy Reform at the Millennium. Stanford, CA: Stanford University Press 2003: 35-8.

'Red-Dotted Document Pardoned Crimes of Private Enterprises and the CCP Hopes to Stop Capital Flow Overseas', Accessed 11 February 2004 at: http:/ / www.lundian. com/forum/view.shtml? $\mathrm{p}=$ PS200402091401001017\&l=chinese

Selected Works of Peng Zhen (1941-1990) 1991, Beijing: People's Press, 1991 (in Chinese).

Shen Jianli 2004. 'Audit in 2004: Not Storm but Transparency'. New Beijing Paper, 30 June 2004. Accessed 6 July 2004 at: http:/ / www1.people.com.cn/GB/jingji/1037/2607051. html

Shi Xiangzhou and Wang Suhuai 2005. 'Look at the Government at a New Platform'. Liaowang News Week, No. 107 March 2005.

'State Council Dealt with the Songhua River Pollution Caused by the Explosion Incident of the Jilin Petroleum Chemical Company'. 24 November 2006. Accessed 24 November 2006 at: http:/ / politics.people.com.cn/GB/1026/5085239.html

'Supreme Court Determines the Review Criteria for Administrative Cases Relating to International Trade'. Accessed 7 September 2002 at: http://www.chinacourt. org/public/ detail.php?id=9779

'Supreme Procurator Explores the Reform on State Compensation Law, Compensation of More than 58 Million for 10 Years of the Law Implementation', New Beijing Daily, 3 January 2005. Accessed 3 January 2005 at: http://www.people.com.cn/ GB/14576/14957/3094389.html 
'The winning rate for ordinary people to sue the officials in China is about $30 \%$ and the revision of the Administrative Litigation Law needs five breakthroughs'. 6 April 2004. Accessed 6 April 2004 at: http:/ / www.hsm.com.cn/node2/node116/node275/ node276/userobject6ai162926.html

'Two Responsible Persons for the Miyun Stampede Accident Were Tried and the Court Hearing Lasted for Seven Hours'. New Beijing Daily, 14 October 2004. Accessed 14 October 2004 at: http:/ / www.people.com.cn/GB/shehui/1063/2917898.html

Wang Binlai 1998. 'Enhance the Administrative Organs to Manage Administration According to Law (Social Survey)'. People's Daily, 7 October 1998.

Wang Ying 2000. 'Graft War Targets the Top'. China Daily, 27 October 2000.

Wen Xiaoli 2004. 'Basic Issues in Legalizing Administrative Openness'. Legal Science 6(2004): 38-40.

- 2004. 'Legal System of Administrative Openness'. Chinese Legal Science 2(2004): 3-4, 11.

Wu Jin 2004. 'Towards Rule-of-Law Government' (Part 1). People's Daily, 22 April 2004.

Xu, Yue and Yu Jie (eds) 1998. Twenty-Year Construction of China's Legal System. Zhengzhou: Zhongzhou Old Books Publisher: 211

Yingyi Qian and Jinglian Wu 2003. 'China's Transition to a Market Economy: How Far Across the River?'. In Nicholas C. Hope, Dennis Tao Yang and Mu Yang Li (eds), How Far Across the River? Chinese Policy Reform at the Millennium. Stanford, CA: Stanford University Press 2003: 35-8.

Ying Songnian 1998. 'Developments of the Chinese Administrative Law'. Zengfa Luntan [Journal of China University of Political Science and Law] 5(1998): 19-20.

Yue Furong 2004. 'Why Is the Openness of Administrative Affairs So Difficult?' Market Daily (Shichang Bao), 29 October 2004.

Yuen Yuen Tang 2005. 'When Peasants Sue En Masse: Large-scale Collective ALL Suits in Rural China'. China: An International Journal 3(1): 24-49.

Zhao Wei 2000. 'Propagandizing Laws to Innumerable Families in Every Corner of the Country' Tribune of Political Science and Law, 3(2000): 154-5

Zheng Yongnian 2000. 'The Politics of Power Succession in Post-Deng China'. Asian Journal of Political Science 8(1): 27.

Zhou Yezhong and Deng Lianfan 2002. New Perspectives on the Construction of the Party Style. Beijing: People's Press: 136.

Zou Keyuan 2004. 'SARS and Rule of Law in China'. In John Wong and Zheng Yongnian (eds). The SARS Epidemic: Challenges to China's Crisis Management. Singapore: World Scientific Publishing Co., 2004: 99-122. 